Шупик I. І., кандидат політичних наук

Полтавська державна аграрна академія

\title{
ПІДВИЩЕННЯ ПРАЦЕЗДАТНОГО ВІКУ ДЛЯ ЖІНОК ЯК ОДИН IЗ ВАЖЕЛІВ ВПЛИВУ НА МАКРОЕКОНОМІЧНУ СИТУАЦІЮ В УКРАЇНІ
}

\section{Рецензент - доктор економічних наук, професор Х. 3. Махмудов}

\begin{abstract}
Стаття присвячена проблемі реформування наиіональної пенсійної системи, зокрема, такому ї̈ аспекту, як підвищення працездатного віку для жінок у контексті покращзання макроекономічної ситуації в краӥні, оскільки без активного використання їх економічного потенціалу в країні немож-

ливі суттєві зміни, відновлення соціальної справедливості. Визначаються фактори, щзо об'єктивно обумовлюють збільшення вікового иензу для жінок, з'ясовується відповідність ичих перетворень сучасним макроекономічним потребам краӥни.
\end{abstract}

Ключові слова: пенсійна реформа, прачездатний вік, економічна трансформація, макроекономічна ситуачія, фемінізачія бідності.

Постановка проблеми. Реформування економіки України потребує активних зусиль державних органів влади стосовно ефективного використання потенціалу трудових ресурсів країни, зокрема, жіноцтва, адже з точки зору потреб національної економіки, змін, що спостерігаються в репродуктивній та міграційній поведінці населення, економічна діяльність жінок - це важлива умова забезпечення економічного зростання країни та покращання добробуту життя іiї громадян. Це, в свою чергу, вимагає змін у підходах до вітчизняної пенсійної системи, звичне функціонування якої вже тривалий період знаходиться під серйозною загрозою, означаючи для країни подальше посилення навантаження на зайняту частину населення для фінансування пенсійних витрат, стимулювання тіньової сфери, деградацію освіти, охорони здоров'я.

Аналіз основних досліджень і публікацій, у яких започатковано розв'язання проблеми. 31 жовтня 2011 р. в Україні вступила в силу пенсійна реформа, але останнім часом, як це було i напередодні парламентських виборів 2012 р., посилюються політичні спекуляції стосовно положення закону про збільшення вікового пенсійного цензу для жінок, - народ вводять в оману обіцянками про відміну цих положень, конкретні об'єктивні аргументи підмінюють власною думкою, а науковий аналіз результатів реформи - емоціями. Саме тому дослідження вітчизняних науковців із цієї проблематики (Е. Лібанової [2], Є. Щєглової, Л. Ткаченко [6] та інших) дозволяють зрозуміти іï необхідність і незворотність.

У грунтовній колективній монографії Інституту демографії та соціальних досліджень імені М. В. Птухи НАН України «Пенсійна реформа в Україні: напрями реалізації» [4] автори аналізують різні аспекти зазначеної проблеми, узагальнюють світовий досвід і можливість його застосування у вітчизняних умовах, пропонують варіанти ії вирішення, прогнозують можливі наслідки. Значний інтерес становлять матеріали дослідження «Аналіз і фінансова оцінка наслідків можливої відміни положень Закону України «Про заходи щодо законодавчого забезпечення реформування пенсійної системи», яке було проведено за ініціативою і на замовлення Проекту USAID «Програма розвитку фінансового сектоpy» [6].

Водночас автор вважає необхідним зосередити увагу на більш детальній аргументації доцільності збільшення пенсійного віку для жінок із метою уникнення навколо цього питання політичної складової, поскільки за цим рішенням стоять суто економічні, прагматичні міркування.

Мета дослідження полягає в тому, щоб визначити фактори, що об'єктивно обумовлюють збільшення вікового цензу для жінок і з'ясувати відповідність цих перетворень сучасним макроекономічним потребам країни.

Завдання: з'ясувати групи факторів, що обумовлюють необхідність підвищення пенсійного віку для жінок; визначити результати пенсійної реформи за 2012 рік.

Методи дослідження: порівняльний, статистичний, аналітичний методи.

Результати досліджень. Протягом останнього десятиріччя середній рівень державних витрат на пенсії відносно до ВВП постійно зростав (до 18$19 \%$ ), чого не могли собі дозволити навіть економічно розвинені європейські країни (в середньому $7 \%$ ). Через це одночасне зростання ви- 
трат на державне пенсійне забезпечення та кількості неактивних верств населення зробило неможливим самостійну підтримку встановлених пенсій солідарної пенсійної системи держави. Тому одним із заходів послаблення пенсійної кризи в країні стало підвищення для жінок віку виходу на пенсію до 60 років, хоча ця норма також не зовсім відповідає мінімальним стандартам пенсійного віку в європейських країнах (табл. 1). Окремі з них, через економічну скруту, готуються до його перегляду як для чоловіків, так і жінок у сторону збільшення.

Так, наприклад, у Швеції, за ініціативою Прем'єр-міністра - до 76 років, у Німеччині та Іспанії- 365 до 67 років; у Великобританії (з 2020 року) - до 66 років, у період 20342036 рр. - до 67 років і до 68 - з 2044 по 2046 роки [13]. До речі, все це співпадає 3 прогнозами П. Друкера, який ще наприкінці 60-х років минулого сторіччя писав, що «сьогодні більша частина населення здатна працювати і в шістдесят П'ять років» [1, с. 240], а у 2001 році прогнозував необхідність збільшення пенсійного віку у найближчі 20-30 років до 79 років [9]. Із пропозицією розпочати 32015 року поступове підвищення пенсійного віку до 63-х років і для чоловіків, і для жінок виступило міністерство фінансів Роciï [12].

В Україні, згідно з діючим законодавством, обрали шлях поступового вирівнювання пенсійного віку для жінок та чоловіків шляхом щорічного збільшення для жінок стажу на 6 місяців i досягнення до 2021 р. 60 років для їх виходу на пенсію (табл. 2).

Отже, одним із соціально-демографічних аргументів стосовно доцільності підвищення пенсійного віку для жінок є світовий досвід. До інших слід віднести:

- існуючу гендерну різницю в доходах жінок i чоловіків, зокрема, рівень зарплати жінок становить $75 \%$ від зарплати чоловіків. Середні пенсії жінок на 500 грн нижчі, ніж у чоловіків, і становлять, відповідно, 827 грн та 1327 грн [10]. До того ж майже 42 \% пенсій за віком, які отримують жінки, менші гарантованого в Україні мінімуму [3];

- значно коротший період накопичення жінками пенсійних внесків (на п'ять років), через що страховий стаж жінок менший, а середня пенсія становить 67 \% від пенсії чоловіків;

- меншу вірогідність смерті жінок у працездатному віці, що сягає для них 8 \% (для чоловіків $-38 \%$ ) [2];

- збереження жінками до 60 років вищого рівня працездатності від економічно активного віку - $90 \%$ (у чоловіків - $60 \%$ ) [2] i, зокрема, $70 \%$ жінок, які вийшли на пенсію, продовжують працювати [5];

\section{1. Пенсійний вік у різних краӥнах свіму [8]}

\begin{tabular}{|c|c|c|c|c|c|}
\hline Країни & Чоловіки & Жінки & Країни & Чоловіки & Жінки \\
\hline Вірменія & 63 & 61 & Португалія & 65 & 65 \\
\hline Казахстан & 63 & 58 & Греція & 65 & 60 \\
\hline Азербайджан & 62 & 57 & Італія & 65 & 60 \\
\hline Молдова & 62 & 57 & Великобританія & 65 & 60 \\
\hline Туркменістан & 62 & 57 & Польща & 65 & 60 \\
\hline Білорусь & 60 & 55 & Франція & 62 & 62 \\
\hline Росія & 60 & 55 & Канада & 65 & 65 \\
\hline Естонія & 63 & 63 & США & 65 & 65 \\
\hline Україна & 60 & 55 & Японія & 65 & 65 \\
\hline Данія & 67 & 67 & Австралія & 65 & 62 \\
\hline Німеччина & 65 & 65 & Аргентина & 65 & 60 \\
\hline Іспанія & 65 & 65 & Чілі & 65 & 60 \\
\hline
\end{tabular}

2. Вік виходу жінок Украӥни на пенсію згідно з реформою

\begin{tabular}{|c|c|c|c|}
\hline Пенсійний вік & Дата народження & Пенсійний вік & Дата народження \\
\hline 55 & до 30.09.1956 включно & 58 & $1.04 .1959-30.09 .1959$ \\
\hline 55,5 & $1.10 .1956-31.03 .1957$ & 58,5 & $1.10 .1959-31.03 .1960$ \\
\hline 56 & $1.04 .1957-30.09 .1957$ & 59 & $1.04 .1960-30.09 .1960$ \\
\hline 56,5 & $1.10 .1957-31.03 .1958$ & 59,5 & $1.10 .1960-31.03 .1961$ \\
\hline 57 & $1.04 .1958-30.09 .1958$ & 60 & $1.04 .1961-31.12 .1961$ \\
\hline 57,5 & $1.10 .1958-31.03 .1959$ & & \\
\hline
\end{tabular}


- значно триваліший період перебування жінок на пенсії після досягнення п'ятидесятип’ятирічного віку - 23,9 роки, що відповідає європейським показникам (табл. 4);

- необхідність подолання фемінізації бідності, адже серед українських пенсіонерів приблизно $64 \%$ - це жінки, які через нерівність доходів матеріально живуть гірше від чоловіків (табл. 5).

Щодо економічних аргументів на користь підвищення пенсійного віку для жінок, то за рік реформи:

- були зекономлені кошти на пенсійних витратах на 1,9 млрд грн, а в 2021 р. економія досягне
36,4 млрд грн [6];

- зменшився дефіцит бюджету пенсійного фонду, який «становить менше $9 \%$ - навіть краще, ніж у багатьох європейських країнах; для порівняння: у 2010 році дефіцит бюджету ПФ становив $18 \%$ (34,5 мільярда), в 2011 - 11,6\% (27,2 мільярда). У 2013 році дефіцит бюджету зменшений майже на чверть - до 21 мільярда гривень» [5];

- на 132 тис. осіб скоротилася загальна кількість пенсіонерів (прогнозні дані на 2021 р. більше ніж 1 млн осіб) [6];

\section{4. Тривалість життя жінок на пенсії в світі *}

\begin{tabular}{|c|c|c|c|}
\hline \multicolumn{2}{|c|}{ На кожні 10 років роботи } & \multicolumn{2}{|c|}{ Загальна (в середньому) } \\
\hline країна & роки & країна & роки \\
\hline Україна & 7,1 & Україна & 23,9 \\
\hline Великобританія & 5,8 & Великобританія & 23 \\
\hline Німеччина & 4,6, & Німеччина & 21 \\
\hline Польща & 5,5, & Польща & 22, \\
\hline США & 3,8 & США & 18, \\
\hline Угорщина & 4,9 & Словаччина & 18 \\
\hline Японія & 5,1 & Франція & 26 \\
\hline & & Росія & 23 \\
\hline
\end{tabular}

Примітка. * Складено автором на основі даних http://newsukraine.com.ua/news/195471-ukrainarekordsmen

\section{5. Гендерний аналіз добробуту пенсіонерів Украӥни *}

\begin{tabular}{|c|c|c|}
\hline Критерії & Жінки & Чоловіки \\
\hline Не вистачає грошей навіть на їжу & $18,7 \%$ & $11,1 \%$ \\
\hline Вистачає грошей на їжу, але купити одяг уже дуже важко & $45,7 \%$ & $42,2 \%$ \\
\hline $\begin{array}{c}\text { Досить грошей на їжу та одяг, можу дещо відкласти, } \\
\text { але цього не досить, аби купувати дорогі речі (холодильник) }\end{array}$ & $30,7 \%$ & $37,5 \%$ \\
\hline $\begin{array}{c}\text { Можу дозволити собі купувати дорогі речі } \\
\text { (телевізор чи холодильник) }\end{array}$ & $3,9 \%$ & $7,9 \%$ \\
\hline Можу дозволити собі купувати все, що хочу & $0,1 \%$ & $0,2 \%$ \\
\hline Труднощі з відповіддю & $0,9 \%$ & $1,1 \%$ \\
\hline
\end{tabular}

Примітка. * Складено автором на основі даних http: newsukraine.com.ua/ tags/5968zhenschina

6. Макроекономічні прогнозні пропозицї [6]

\begin{tabular}{|c|c|c|c|}
\hline Показник & $\begin{array}{c}2012 \mathrm{p} . \\
\text { (фактичні дані } \\
\text { або оцінка) }\end{array}$ & $2015 \mathrm{p}$. & $2020 \mathrm{p.}$ \\
\hline Зростання споживчих цін, \% & 0,6 & 5,0 & 3,5 \\
\hline Зростання реального ВВП, \% & 0,2 & 2,5 & 3,5 \\
\hline Зростання реальної заробітної плати, \% & 14,4 & 6,0 & 4,5 \\
\hline Рівень економічної активності осіб у віці & & & 76,5 \\
18-64 роки, \% & 76,5 & 76,5 & 64,2 \\
$\begin{array}{c}\text { чоловіки } \\
\text { жінки }\end{array}$ & 64,2 & 64,2 & 6,1 \\
\hline Рівень безробіття, \% & 7,6 & 7,1 & 68,0 \\
\hline Рівень залучення зайнятих до участі & 68,0 & 68,0 & \\
в пенсійному страхуванні, \% & &
\end{tabular}


- підвищилася кількість зайнятих (у тому числі скоротилося безробіття серед молоді), завдяки чому на 100 платників пенсійних внесків припадатиме менше 102 пенсіонерів (без реформи 111) [6].

Окрім того, макроекономічні прогнозні розрахунки Інституту демографії та соціальних досліджень імені М. В. Птухи (табл. 6) дозволяють зрозуміти, як зазначає його провідний науковий співробітник Л. Ткаченко, що «цей реформаторський захід надає можливість ефективно стри-

\section{БІБЛІОГРАФІЯ}

1. Друкер П. Ф. Эпоха разрыва: ориентиры для нашего меняющегося общества ; Пер. с англ. М. : ООО «И. Д. Вильямс», 2007. - 336 с.

2. Либанова Э. Ранний выход на пенсию украинских женщин - дискриминация или привилегированное положение? [Електронний ресурс] / Режим доступу: http://www.feminist.org.ua /library/gender/txt/pens.php

3. Пенсионный возраст должен быть одинаковым» [Електронний ресурс] / Режим доступу: http://pregions.od.ua/?page $=$ showmore \&style $=$ news \&id $=1930$

4. Пенсійна реформа в Україні: напрями реалізації (колективна монографія) / За ред. Е. М. Лібанової. - К. : Ін-т демографії та соціальних досліджень імені М. В. Птухи НАН України, 2010. $270 \mathrm{c}$.

5. Пенсійна реформа: чому повертати назад уже не можна //Село полтавське. -18 квітня 2013. C. 9 .

6. Ткаченко Л. Последствия возможной отмены пенсионной реформы / Л. Ткаченко // Зеркало недели. Украина. - 20 апреля 2013. - С. 10. мувати збільшення навантаження на пенсійну систему та комплексний ефект» [6].

Висновок. Отже, підвищення пенсійного віку для жінок - це своєрідний захисний механізм, що сприятиме вирішенню проблеми фемінізації бідності, стимулюватиме стійкий макроекономічний розвиток, адже без активного використання економічного потенціалу українських жінок неможливо розраховувати на якісні зміни економічного буття нашого суспільства, забезпечити відновлення соціальної справедливості.

7. Украина рекордсмен по пребыванию женщин на пенсии. - [Електронний ресурс] / Режим доступу: http://newsukraine.com.ua/news/195471ukraina-rekordsmen

8. Шупик I. I. Пенсійна реформа України: необхідність та ризики / I. I. Шупик // Науковопрактична конференція професорсько-викладацького складу за результатами науково-дослідної роботи за 2010 рік (25-26 квітня 2010 р.) : тези виступів викладачів кафедри економічної теорії та економічних досліджень. - ПДАА, 2011. C. 36-40.

9. Ярославский М. 7 миллионов молодых пенсионеров лишают своих старших коллег достойной пенсии [Електронний ресурс] / Режим доступу: //polemika.com.ua/news-67007.html

10. http: newsukraine.com.ua/ tags/5968zhenschina 11. http://ubr.ua/ukraine-and-world/power/v-ukraine -sredniaia-pensiia-mujchin-na-500-grn-vyshe-chemu-jenshin-74021.

12. http://rus.ruvr.ru/2012_03_21/69170036/

13. http://interfax.ru/society/txt.asp?id=241857 